STE WOB

ERP SISTEMI KAO PODRŠKA ELEKTRONSKOM POSLOVANJU ORGANIZACIJA: EVALUACIJA MOGUĆIH ALTERNATIVA

\author{
ERP SYSTEMS SUPPORT FOR ORGANIZATIONAL \\ E- BUSINESS: EVALUATION OF POSSIBLE \\ ALTERNATIVES
}

\title{
Žarko Rađenović
}

Ekonomski fakultet, Univerzitet u Nišu, Niš, Srbija

CMESTE

JEL Category: L84, M21

\begin{abstract}
Apstrakt
Ubrzani razvoj tehnike i tehnologije omogućio je mnogim organizacijama da u svom poslovanju koriste i tehnologiju koja se bazira na veb alatima. Takve organizacije u tom slučaju moraju biti podržane jakim infrastrukturama i platformama koje im mogu pružiti efikasno funkcionisanje, a jedna od njih jeste ERP (Enterprise Resource Planning) sistem za planiranje resursa preduzeća. Ovaj se sistem upotrebljava $u$ poslovnim procesima kod organizacija sa širokom lepezom aktivnosti, kako bi se prevazišla uska grla lanca snabdevanja koja sprečavaju efikasan protok proizvoda od trenutka kada su oni samo sirovine do trenutka njihove finalne isporuke potrošačima/klijentima. Ovaj rad se upravo bavi evolucijom odnosa, odnosno povezivanja, između sistema za planiranje resursa preduzeća i elektronskog poslovanja. $U$ radu je prikazano na koji način organizacije i kompanije mogu korišćenjem ovog sistema da ostvare koristi u vidu konkurentskih prednosti u odnosu na svoje rivale evaluacijom i izborom odgovarajućih alternativa za ERP. Kako bi se uspešno koristio princip rada ERP sistema, neophodno je formirati odgovarajući okvir elektronskog upravljanja lancima snabdevanja koji bi integrisao sve poslovne procese jednog lanca snabdevanja. Sve ovo se ostvaruje jednim novim sredstvom tehnologije koje osposobljava elektronski lanac snabdevanja za funkcionisanje u virtuelnoj sredini računarstva u oblaku. ERP sistem pruža organizacijama sigurnost $u$ elektronskoj trgovini $i$ izazovima koji proizilaze iz elektronskog poslovanja. Zato aktivno praćenje novih tehnologija poslovanja na Internetu koje doprinose profitabilnijem poslovanju, a povezane su sa ERP-om i elektronskim lancem snabdevanja predstavlja imperativ današnjeg savremenog poslovanja.
\end{abstract}

Address of the author:

Žarko Rađenović

拝=" zarkoradjenovic@hotmail.com
KIjučne reči: ERP sistemi, elektronsko poslovanje, organizacije 


\begin{abstract}
The rapid development of technology has enabled many organizations to use in their operations technology based on web tools. Such organizations in this case must be supported by a strong infrastructure and platforms that can provide them effective functioning. One of them is the ERP (Enterprise Resource Planning) system. This system is used in business processes in organizations with a wide range of activities, in order to overcome the bottlenecks of the supply chain that prevent the efficient flow of products from the moment they are just raw material to the moment of its final delivery to customers/clients. This work deals with the evolution of the relationship and connections between systems for enterprise resource planning and e-business. The paper presents how organizations and companies can use this system to obtain benefit in the form of competitive advantages over its rivals by choosing and evaluate ERP alternatives. In order to successfully use the principles of ERP systems' operations, it is necessary to establish the appropriate framework of the electronic supply chain management that integrates all business processes of one chain (E-SCM Supply Chain Management). All this is achieved with a new technology tool that enables electronic supply chain to function in such a virtual environment as the cloud computing is. ERP system provides to organizations security in electronic commerce and in the challenges resulting from the electronic business.
\end{abstract}

Keywords: ERP systems, e- business, organization

\section{UVOD}

$\mathrm{U}$ današnje vreme, komparativna prednost jedne organizacije podrazumeva njenu sposobnost da brzo i kvalitetno odgovori na informacije odnosno zahteve koje one nose kroz lanac snabdevanja. Ovo pomaže da se stvara dodatna vrednost duž čitavog lanca snabdevanja a to se ostvaruje upravo pravovremenim prenosom informacija koje služe za pravovremeno donošenje odluka. Tehnologije bazirane na veb-u koje se primenjuju u organizacijama upravo povećavaju i usavršavaju gore spomenutu sposobnost. Ove tehnologije stvaraju specifičnu mrežu vrednosti koja podrazumeva integraciju svih učesnika u lancu snabdevanja, pri čemu se transmisija informacija i odluka koristi za uvećanje vrednosti kroz lanac snabdevanja putem interakcije učesnika iz mreže vrednosti. Pri tome neophodno je napomenuti da se svaki od učesnika lanca snabdevanja, korišćenjem veb tehnologije i sistema planiranja resursa preduzeća, specijalizuje za svoju delatnost.

Sistem planiranja resursa preduzeća u visoko konkurentnom okruženju pruža organizacijama protok informacija putem elektronskog poslovanja pri čemu takav proces postaje gotovo nezamenljiv u savremenom poslovanju, kada je u pitanju komunikacija između partnera u lancu snabdevanja i razmena podataka. Koordinacijom
ERP sistema i elektronskog poslovanja ostvaruje se pravilna i korisna dvosmerna razmena informacija u lancu snabdevanja, što samo potvrđuje da ERP i elektronsko poslovanje nisu konkurentni sistemi.

Benefiti koji se ostvaruju primenom ova dva sistema upravo počivaju na njihovom komplementarnom sadejstvu. Zbog toga se i kaže, da se pravovremena isporuka i ispunjavanje zahteva klijenata ostvaruje kohezijom aktivnosti ERP-a i elektronskog poslovanja. Da bi se ovo ostvarilo, softverski provajderi moraju razviti ERP sistem tako da ne dolazi do konflikta njegovih ciljeva sa ciljevima elektronskog poslovanja. To podrazumeva razvoj ERP sistema koji će biti apsolutno interaktivan $\mathrm{i}$ primenljiv $\mathrm{u}$ realnom vremenu i koji će omogućiti upravljanje informacijama i podacima i elektronski, kako se ideje ne bi gubile i kako sprovodila analiza podataka i poslovanja u realnom vremenu.

Pored toga što nude prodaju ERP sistema, provajderi organizacijama nude i softver za razvoj elektronske trgovine koji je povezan sa sistemom za planiranje resursa preduzeća. Ova prodaja ERP softvera zajedno sa softverom elektronske trgovine omogućuje potrošačima da efikasno sprovode transakciju on- line. Softver elektronske trgovine i podržavajući sistemi kao što je ERP moraju biti tako integrisani da simultano upravljaju svim organizacionim procesima. 


\section{KLJUČNI ASPEKTI RAZVOJA ERP-A I ELEKTRONSKOG POSLOVANJA}

ERP sistemi odnosno sistemi planiranja resursa preduzeća udahnuli su organizacijama i kompanijama jedan novi poslovni život baziran na web tehnologijama. Ovo podrazumeva da ERP pomaže pravilnoj razmeni i ažuriranju informacija kroz organizaciju i dalje nastavlja kooperaciju sa elektronskim poslovanjem koje tu informaciju prenosi u spoljni svet to jest u poslovni ambijent grane u kojoj preduzeće obavlja svoju delatnost. Ukratko, planiranje resursa preduzeća i elektronsko poslovanje međusobno dopunjuju jedan drugog pa je zato na početku uspostavljanja njihove veze neophodno definisati i odnos između istih:

- Uspostavljanje standarda koji definišu međusobni odnos sistema planiranja resursa preduzeća i elektronskog poslovanja koji će doprineti ostvarivanju konkurentske prednosti zajedničkim delovanjem ovih dveju tehnoloških alata.

- Istraživanje sposobnosti odnosno mogućnosti polivalentnog povezivanja ovih sistemu među različitim organizacijama a sve u cilju povećanje efikasnosti samog lanca snabdevanja.

- Razvoj elektronskog lanca snabdevanja i formiranje računarstva u oblaku za njegove potrebe kojeg će koristiti svi učesnici lanca snabdevanja.

Termin planiranje resursa preduzeća (ERP) iskovan je još u ranim devedesetim godinama od strane Gartner Group (2016), i ovi sistemi su kontinuirano evoluirali u skladu i uporedo sa razvojem samog poslovanja na Internetu kao i tehnologija. Mnogi analitičari se slažu da planiranje resursa preduzeća nije samo softverski paket koji pruža podršku za elektronsko poslovanje, već ERP sistem predstavlja kombinaciju različitih poslovnih procesa koji svojom integracijom i kompleksnošću pomažu organizaciji u traženju najefikasnijeg rešenja za poslovanje. Postoji nekoliko funkcionalnih aspekata koji planiranje resursa preduzeća preporučuje kao sistem koji u budućnosti elektronskog poslovanja može biti značajan kompetitivni instrument mnogih kompanija, naravno uz konstantno usavršavanje i nadograđivanje, a to su:

- Proširenje kapaciteta lanca snabdevanja

- Planiranje i izvršavanje marketinških aktivnosti

- Upravljanje zalihama u magacinima i skladištima

- Naručivanje

- Fakturisanje

- Isporučivanje proizvoda krajnjim kupcima uz delegiranje aktivnosti za efikasno izvršenje ovog procesa.

Korišćenjem pak posebnog sistema za integraciju aplikacija, sistem planiranja resursa preduzeća može biti povezan sa ostalim delovima organizacije. Naime, organizacija koja usvaja sistem planiranja resursa preduzeća standardizuje svoje procese i operacije i omogućuje integraciju finansijskih informacija i narudžbina od strane potrošača. Na ovaj način dolazi do pravilne implementacije ERP sistema koja se kasnije reperkutuje i na efikasnu primenu ERP-a za elektronsko poslovanje. Prednosti Interneta kao i brzo rastuće, kompleksno i visoko konkurentno tržište i njegov ambijent, čine poslovanje organizacije odgovornim za zadovoljenje tražnje i specifičnih zahteva potrošača unapređenjem i očuvanjem vrednosti proizvoda duž čitavog lanca snabdevanja a pogotovo onog virtuelnog, putem elektronskog poslovanja. Ovo sve omogućuje i podrška ERP-a koji je postao jedan od najznačajnijih delova lanca snabdevanja kada je u pitanju softverska podrška. Tako se može videti da sistemi planiranja resursa preduzeća podržavaju elektronsko poslovanje kroz:

$$
\begin{aligned}
& \text { - Internet pristup i veb tehnologije } \\
& \text { - } \quad \text { Aplikativni okvir kroz XML rešenja } \\
& \text { - Kastumizacija interfejsa. }
\end{aligned}
$$

ERP sistem koji je se zajedno sa Internetom usvaja u jednoj organizaciji omogućuje sprovođenje budućih IT inicijativa u okviru elektronskog poslovanja kao što su:

$$
\begin{aligned}
\text { - } & \begin{array}{l}
\text { Integracija članova u okviru lanca } \\
\text { snabdevanja }
\end{array} \\
\text { - } & \begin{array}{l}
\text { Povećanje kapaciteta i sposobnosti } \\
\text { elektronske trgovine }
\end{array} \\
\text { - } & \text { Poboljšanje procesa organizacionog učenja }
\end{aligned}
$$


- Uklanjanje funkcionalnih područja koja smanjuju efikasnost i integraciju.

Kada se govori o razvoju sistema planiranja resursa preduzeća i elektronskom poslovanju neophodno je naglasiti značaj ovog razvoja kod malih i srednjih preduzeća. Naime, uvođenjem sistema planiranja resursa preduzeća baziranog na Internetu kod malih i srednjih preduzeća, poboljšava se vreme odgovora na izazove iz okruženja i njegove promene koji bi ukoliko nema pravog tajminga mogli ugroziti poslovanje date organizacije. Ovako, uz pomoć ERP sistema i veb tehnologija kod malih i srednjih preduzeća dolazi do:

- Poboljšanja performansi organizacije

- Ostvarivanja njenih ciljeva u virtuelnom poslovanju

- Uklanjanje barijera u uvođenju tehnologije

- Uvećanje konkurentnosti

- Prevencija protiv napada rivala sa tržišta

- Unapređenje produktivnosti

- Smanjivanje jaza između date organizacije i lidera u grani.

Kreiranje, integrisanog intra-organizacionog sistema planiranja resursa preduzeća i njegov razvoj zajedno sa elektronskim poslovanjem preduzeća na Internetu rezultira:

- Novim poslovnim procesima

- Novim zadacima menadžmenta preduzeća

- Različitim organizacionim ponašanjem

- Infrastrukturnim promenama u organizaciji

- Integraciji heterogenih informacionih sistema

- Širenjem aplikativnog okvira kroz organizaciju.

- Pristupanje razvoju kolaborativnih sistema sa učesnicima lanca snabdevanja.

Proces implementiranja sistema planiranja resursa preduzeća u jednu organizaciju kao i njegovo zajedničko korišćenje sa elektronskim poslovanjem vodi ka većim inovacijama u samoj organizaciji. Nekoliko studija je pokazalo da dinamičnost elektronskog poslovanja koja se dobija uvođenjem i prihvatanjem sistema planiranja resursa preduzeća može biti iskorišćena u svrhu strategijskog planiranja daljeg stvaranja vrednosti u organizaciji. Na ovaj način, posmatranjem elektronskog poslovanja i sistema planiranja resursa preduzeća u organizaciji kroz strategijsku prizmu, dolazi do stvaranja jedne potpuno nove paradigme B2B (business-tobusiness) odnosa, koja ima za krajnji cilj poboljšanje performansi elektronskog poslovanja i korišćenja veb alata. Kako bi se ostvarili ovi ciljevi kao i ciljevi postavljeni na bazi spoljašnjih tendencija koje vladaju u konkurentskoj, tržišnoj areni, neophodno je implementirati ERP koji će ispoljiti sve svoje sposobnosti kroz (Mabert, Soni, \& Venkataramanan, 2003):

- Targetiranje ključnih područja poslovnog procesa za ostvarivanje željenog cilja

- Razvoj internih poslovnih procesa za poboljšanje performansi $u$ odnosu na konkurente

- Unapređenje operativnih kapaciteta

- Proširenje delatnosti odnosno aktivnosti u oblasti pružanja usluga korisnicima/potrošačima

- Poboljšanje protoka informacija kroz onaj deo lanca snabdevanja za koji je odgovorna data organizacija.

Upotreba sistema planiranja resursa preduzeća u konkurentske svrhe pogotovo na virtuelnom nivou za koje je zaduženo elektronsko poslovanje, često iziskuje sprovođenje svojevrsnog benčmarking procesa. Kao što je ranije pomenuto, ERP sistem i njegove prednosti se koriste na onaj način odnosno približno kako ga koristi preduzeće lider u datoj oblasti i zato se valja truditi oko sustizanja lidera u poslovanju. Ovo podrazumeva da se kompleksnost, implementacija, tajming i troškovi uvođenja sistema planiranja resursa preduzeća smanjuju sa smanjenjem dispariteta između lidera i organizacije koji posluju u istoj grani. Povećanje konkurentske prednosti ERP-om, analizom benčmarking rezultata ogleda se u:

- naprednom modeliranju ERP sistema i njegovoj primeni u rešavanju problema

- prilagođavanju i integraciji sa drugim sistemima preduzeća

- fokusiranjem na uvećanje tržišnog učešća

- prognoziranjem

- upravljanjem odnosa sa potrošačima

- elektronskoj trgovini.

Sistem planiranja resursa preduzeća pokriva mnogobrojne funkcionalne delove jedne 
organizacije pa se tako ti delovi ERP-a često nazivaju ERP modelima koji su grupisani na sledeći način:

- Finansijsko računovodstvo

- Upravljačko računovodstvo

- Upravljanje ljudskim resursima - planiranje, regrutovanje, selekcija, zapošljavanje kadrova

- Proizvodnja - inženjering, upravljanje kapacitetom, upravljanje kvalitetom, životni ciklus proizvoda

- Proces naručivanja - primanje narudžbi, fakturisanje, naplata, analiza i izveštavanje, kreditiranje

- Lanac snabdevanja - konfiguracija lanca, upravljanje zalihama, odnosi učesnika

- Projektni menadžment - projektno planiranje, planiranje resursa, projektovanje troškova, upravljanje aktivnostima

- Upravljanje odnosa sa potrošačima - callcentri, prodaja i marketing

- Upravljanje podacima - različiti servisi koji putem interfejsa omogućuju komuniciranje sa potrošačima, dobavljačima, distributerima i unutar preduzeća između zaposlenih.

Implementacija najboljih praksi sistema planiranja resursa preduzeća nakon benčmarkovanja samo pomaže da se uvedu oni ERP sistemi koji neće dovesti do greške. Mnoge kompanije ukoliko ne izaberu adekvatan sistem planiranja resursa preduzeća često se susreću sa greškama u lancu snabdevanja prilikom protoka proizvoda i usluga. Obično za ispravku nastalih grešaka mora da prođe određeni period prilagođavanja kako bi se uspostavio normalan tok u lancu ukoliko kompanije u međuvremenu ne zamene dati ERP. Takođe, ukoliko ERP sistem donosi odmah zadovoljavajuću stopu prinosa za investiciju koja je učinjena za uvođenje istog, ne znači da nije dobar, već je prosto potrebno da prođe jedan period prilagođavanja kod svih članova lanca i u samoj organizaciji naravno. $U$ početnom periodu adaptacije, odnosno u primeni sistema planiranja resursa preduzeća, nakon njegovog implementiranja, troškovi su ponekad i za $50 \%$ viši od benefita koji će tek kasnije ostvariti značajniju vrednost, kada ERP zaživi u organizaciji. Implementacija ERP sistema i njeni benefiti osetiće se u organizaciji tek kada se prođe kroz sledećih deset manjih faza odnosno ciklusa prilagođavanja (Mabert, Soni, \& Venkataramanan, 2003):

- Korisnici moraju definisati ciljeve koje žele ostvariti korišćenjem ovog sistema i pratiti njegove smernice kako bi se povećala profitabilnost. Takođe neophodno je analizirati kapacitet sistema koji pruža provajder i njegovu sposobnost da ispuni postavljene ciljeve. U ovom ciklusu se prati svaka komunikacija između članova u lancu snabdevanja i svaka transakcija koja se izvrši od strane date organizacije odnosno kompanije.

- U narednih četiri do pet meseci od usvajanja sistema planiranja resursa preduzeća, dolazi do razvijanja projektnog plana koji pored ostvarenja postavljenih ciljeva, ima za zadatak da prilagodi sistem prema karakteristikama date organizacije i obezbedi sigurnost transakcija kroz kanale lanca snabdevanja.

- Ovaj ciklus podrazumeva identifikovanje kritičnih poslovnih procesa koji bi potencijalno pravili problem u toku komunikacije između lanca snabdevanja. Takođe, ovde se sprovodi doslovno podešavanje operacija organizacije na način koji osigurava efikasno poslovanje.

- Kako bi se postigla željena stopa prinosa neophodno je definisati troškove koje je organizacija spremna da podnese što se dobija analizom ključnih oblasti odnosno polja poslovanja koje bi tangiralo uvođenje sistema planiranja resursa preduzeća.

- Formiranje tima eksperata sa određenim nivoom kredibiliteta uz tehničku i finansijsku podršku koji će kontrolisati implementaciju čitavog procesa.

- Distribucija resursa tokom razvoja projektnog plana mora biti tako raspoređena da osposobi organizaciju da efikasno koristi sistem planiranja resursa preduzeća.

- Identifikacija poslovnih procesa u organizaciji još za vreme pilot faze kako ne bi došlo do stvaranja uskih grla u protoku informacija $i$ transakcija.

- Sprovođenje edukacije zaposlenih kako bi se na vreme spoznao način funkcionisanja sistema planiranja resursa preduzeća.

- Registrovanje problema koji ometaju sprovođenje projektnog plana a samim tim i 
sistema planiranja resursa preduzeća i preventivno delovanje počevši od pomenute edukacije do neizostavnog izdvajanja finansija za praćenje najnovijih tehnologija.

- Redovno ažuriranje podataka i skladištenje u bazi podataka kako samog preduzeća tako i ostalih članova lanca snabdevanja.

Tehnologije bazirane na veb-u omogućuju lakši protok i upravljanje informacijama između preduzeća $a$ to je sve olakšano sistemom planiranja resursa preduzeća. Takođe, ERP sistem pomaže i razvijanju odnosa ne samo na relaciji B2B (business-to-business) nego i na relaciji B2C (business-to-customer) pri čemu se stvara jedna ambijentalna celina za razmenu informacija među zaposlenima i stejkholderima. Bilo kako bilo, potrebno je shvatiti da sistem planiranja resursa preduzeća zapravo predstavlja jednu vrstu transmisionog motora u organizaciji od čijeg prenosa informacija zavisi odnos svih učesnika lanca snabdevanja za svaku kompaniju koja i malo želi biti ozbiljna u svom poslovanju. Upravo je dokazano da sistem planiranja resursa preduzeća kao glavni pokretač razmene informacija i podataka pravi prostor za uspešno delovanje elektronskog poslovanja. Jednostavno, u savremenim organizacijama, koje izdvajaju značajna sredstva za poslovanje putem i preko Interneta, proces elektronskog poslovanja je nemoguće zamisliti bez infrastrukture koja joj daje kapacitet za korišćenje tehnoloških resursa.

\section{UTICAJ ERP-A NA PROTOK INFORMACIJA I E-TRGOVINU}

Kada govorimo o povezanosti sistema planiranja resursa preduzeća sa tipovima elektronskog poslovanja, neophodno je reći da su portali jedan od najvažnijih tipova razmene iskustava $i$ informacija o poslovnim procesima i proizvodima u poslednje vreme. Tako postoji nekoliko vrsta virtuelnih portala koji se najčešće koriste kao dopuna elektronskom poslovanju preduzeća podržanom od strane nekog ERP sistema (Damanpour, 2001):

- Tržišno bazirani portali - mnogi ERP provajderi formiraju portale kao proširenu listu ponude dobara i usluga koje nude kako bi potrošači mogli da se što lakše opredele za željeni proizvod sa određenim karakteristikama na virtuelnom tržištu. ERP softver radi kao agregator koji povezuje organizacije sa njihovim potrošačima uz direktno definisanje uslova kupoprodaje odnosno trgovine. Veći proizvođači ERP softvera ugrađuju platforme SAP i Oracle kako bi baza proizvoda dobila kvalitetniji pristup.

- Korporativni portali- ovi portali omogućuju zaposlenima u organizaciji da međusobno komuniciraju razmenjujući iskustva na poslu i dokumentaciju, a sve u cilju kompletiranja poslovnog okruženja i efikasnije radne sredine. Ovi portali imaju veb interfejs koji disperzuje aplikacije po celoj organizaciji kako bi zaposleni lakše komunicirali.

- Vertikalno orijentisani portali - vertikalni hub portali targetiraju specifičnu grupu organizacija u okviru jedne industrije odnosno privredne grane. Za razliku od tržišnih portala koji se više baziraju na komercijalizaciji, vertikalni hub portali kao što su PlasticNet.com i ChemNet pružaju usluge transakcije i ostali sadržaj za određenu granu industrije.

- Poslovni portali- podrazumevaju postojanje internih i eksternih aplikacija za snabdevanje informacijama iz različitih izvora. Tradicionalna klijent- server tehnologija koja se koristi kod ovih portala omogućuje pristup različitim aplikacijama. Ove aplikacije dopuštaju potpunu odvojenost organizacija, fizičku i geografsku.

- Portali povezani sa ERP sistemom- kod ovih portala organizacije koriste integrativni aplikativni okvir za kompanije EAI (Enterprise Application Integration).

Neke od najčešće korišćenih platformi gore navedene kod tržišno baziranih portala koriste različite module kako bi povezale sistem planiranja resursa preduzeća sa upravljanjem odnosima sa potrošačima i sa upravljanjem lancem snabdevanja. Pa tako pomenuti Oracle koristi nekoliko različitih platformi za usvajanje ERP sistema od kojih se izdvajaju (Oracle, Oracle ERP software review, 2016):

- E-business platforma- pomaže kompanijama tako što pruža intelektualne usluge preko svojih razvijenih aplikacija koje se obično odnose na prodaju, marketing, upravljanje 
ljudskim resursima i proces donošenja odluka. Obično ovakav sistem nudi preko 2.100 inovacija koje se mogu upotrebiti u cilju povećanja profitabilnosti i konkurentnosti. Bazira se na trodelnoj arhitekturi koja podržava formate kao što su XML, HTML, JAVA, SQL i ostali. (Oracle, Oracle Ebusiness Suite, 2016)

- Siebel- platforma za automatsko upravljanje prodajnim kapacitetima koja takođe omogućuje automatsko prilagođavanje turbulentnim promenama na tržištu. (Oracle, Siebel CRM Technology, 2016)

- Peoplesoft- softver za upravljanje finansijama putem ERP-a koji se pre svega koristi u kompleksnim poslovnim sistemima. Ovaj softver sprovodi kombinaciju između različitih proizvoda odnosno usluga jedne organizacije, kako bi se mogle koristiti prednosti obe strategije poslovanja koje su vezane za te proizvode/usluge. (Oracle, PeopleSoft, 2016)

- SunMicrosystems-kombinuje tehnologije koje daju najbolje rešenje za razvoj sistema planiranja resursa preduzeća koji će pomoći u upravljanju organizacijom u kriznim situacijama i redukovati troškove. (Scavo, 2006)

- UNDP-United Nations Development Program za pristup jednoj velikoj ERP bazi koja pomaže lakšem prodiranju na međunarodna tržišta.

Takođe, sa druge strane SAP predstavlja vodećeg provajdera kada je u pitanju primena sistema planiranja resursa preduzeća na organizacijama različitih veličina, odnosno ovaj provajder je poznat po svojoj fleksibilnosti. Ova fleksibilnost mu pomaže da se lakše prilagodi svim ključnim poslovnim funkcijama jedne kompanije koja izlazi na tržište bez obzira na njenu delatnost. Tako su se preko ovog provajdera razvili nekoliko proizvoda koji pomažu efikasnom upravljanju sistemom planiranja resursa preduzeća:

- BusinessOne

- MYSAPERP

- Business Suite

- All-in-one CRM

E-trgovina napravila je najveću revoluciju u načinu prodaje proizvoda i relativno niskoj ceni. Često dolazi do pojave negativnih efekata odvojenog korišćenja platformi za elektronsku trgovinu i sistema planiranja resursa preduzeća. Dobijanje podataka o elektronskoj trgovini na osnovu ERP sistema pospešuje efikasnost $u$ donošenju poslovnih odluka. Postoji nekoliko ključnih prednosti u interakciji koja nastaje između ERP-a i elektronske trgovine (Bendoly \& Kaefer, 2004):

- Povećanje funkcionalnosti: dostupnost podataka u realnom vremenu iz ERP sistema omogućuje korisnicima da vide dostupne zalihe, najnoviji status naloga, i prate pošiljke sa brojevima za njihovu identifikaciju. Ovo pomaže u smanjenju troškova poslovanja i poboljšava korisničko iskustvo.

- Smanjenje troškova zaliha tako što se često vrši ažuriranje informacija o prodaji: Sve veb prodaje i informacije će se odmah pojaviti u ERP sistemu. ERP zalihe artikala će takođe biti ažurirane na osnovu ovih veb transakcija. Dakle, uz konstantno ažuriranje informacija iz veb prodaje i zaliha, ERP korisnik može pravilno planirati kupovinu i na taj način smanjiti troškove zaliha.

- Generisanje finansijskih izveštaja na bazi prometa i informacija iz ERP-a: E-commerce aplikacije su u stanju da generišu finansijske izveštaje o prodaji. Ali integracija sa ERP daje trgovcima sposobnost da izrade bilans stanja, privremeni bilans, protok novca, itd. koji daje transparentnost o finansijskim informacijama širom organizacije.

- Povećanje interne produktivnosti: Integrisani sistem čini efikasnijim više poslovnih procesa, što je smanjuje učešće ljudskih resursa u ovim procesima. Veb prodaja naloga je integrisana u ERP sistem u realnom vremenu, što stvara svojevrsni feedback učesnika u jednoj transakciji.

- Smanjenje angažovanja ljudi, redundantnosti podataka i grešaka

- Povećanje zadovoljstva potrošača

- Bolja kontrola poslovanja.

\section{INTEGRACIJA ERP SISTEMA I PROCES UPRAVLJANJA LANCEM SNABDEVANJA}

Upravljanje lancem snabdevanja definiše se kao sistematska, strategijska, tradicionalna, poslovna funkcija koja koordinira poslovnim funkcijama u 
datoj kompaniji kako bi se dugoročno unapredile performanse lanca snabdevanja svake organizacije koja je učesnik istog. Ključni resurs za efektivno upravljanje lancima snabdevanja jeste adekvatna informacija odnosno njihovo deljenje. Ovo upućuje na integracioni proces svih organizacija kroz čitav lanac snabdevanja. Sistem planiranja resursa preduzeća je u slučaju lanca snabdevanja ključna karika za profitabilno izvršenje procesa (Farzin \& Nezhad, 2010):

- Primanja porudžbine

- Nabavke

- Upravljanja resursima preduzeća

- Upravljanje i planiranje zaliha

- Finansijskog izveštavanja.

Za uspešno upravljanje lancem snabdevanja nije dovoljan samo adekvatan ERP sistem već ovaj sistem mora biti podržan i sa nekoliko ostalih sistema koji su sastavni deo svake organizacije $i$ šire posmatrano svakog sistema interakcije u okviru lanca snabdevanja:

- Upravljanje ljudskim resursima

- Upravljanje transportom

- Upravljanje odnosima sa potrošačima

- Upravljanje zalihama u skladištima.

Kao što je gore spomenuto ERP sistemi igraju ključnu ulogu u procesu integracije seta aplikacija za širenje sistema poslovanja i automatsko obavljanje određenih procesa u međuorganizacionim interakcijama unutar lanca snabdevanja. Poslednjih desetak godina $u$ literaturi su se izdvojile četiri vrste integracija koje doprinose efektivnošću lanca snabdevanja (Akkermans, Bogerd, Yucesan,\& van Wassenhove, 2003):

- Interna unakrsna integracija zajedničkih procesa različitih organizacija

- Integracija unazad sa određivanjem vodećeg snabdevača unutar lanca snabdevanja na primarnom i sekundarnom nivou

- Integracija unapred sa određivanjem vodećeg snabdevača unutar lanca snabdevanja na primarnom i sekundarnom nivou

- Kombinacija prethodne dve integracije.

Pored ove četiri vrste integracija u literaturi se izdvajaju i dve skraćene verzije integracija koje se baziraju na drugim dimenzijama, a to su integracija na bazi protoka informacija i integracija na bazi organizacione strukture učesnika lanca snabdevanja. Uticaj interneta na lanac snabdevanja, ukoliko se organizacija bavi elektronskim poslovanjem dovodi do definicije četiri ključne dimenzije neophodne za integraciju članova lanca snabdevanja (Srinivasan \& Dey, 2014):

- Informaciona integracija- dimenzija integracija koja uključuje deljenje informacija u realnom vremenu i sposobnost smanjenja efekta jakog biča uz brz odgovor na tržišne promene.

- Sinhronizovano planiranje kao dimenzija čiji je fokus na prognozi i kolaboraciji koja bi takođe trebalo da rezultira smanjenju efekta jakog biča i efikasnijem izvršavanju porudžbine, saradnjom svih učesnika u lancu snabdevanja.

- Koordinacija radnih procesa kao dimenzija koja automatski integriše poslovne procese vezane za produktivnost, planiranje, nabavku, naručivanje $\mathrm{i}$ isporuku.

- Kreiranje novog poslovnog modela koji vodi ka promovisanju novog proizvoda, njegovom daljem razvoju i ulasku na nova tržišta.

Uspešna implementacija ERP sistema ima značajnu ulogu u poboljšanju performansi samog lanca snabdevanja i njegove efikasnosti. Ovo omogućuje integraciju internih procesa $u$ organizaciji kao i poboljšanje odnosa između partnera u lancu snabdevanja. Uloga sistema planiranja resursa preduzeća je veoma značajna $s$ obzirom na to da se $u$ današnje vreme preduzeća suočavaju sa povećanim volumenom informacija koji sve više usložnjava i komplikuje radnu okolinu koja postaje sve više dinamična. Sistem planiranja resursa preduzeća pruža lancu snabdevanja sposobnost inoviranja i fleksibilnost koja uvećava efikasnost i otpornost. Kako bi se unapredio lanac snabdevanja sistem planiranja resursa preduzeća mora biti usvojen na taj način da širi znanje i svest članova lanca snabdevanja o značaju protoka informacija. Tako na primer, organizacije korišćenjem sistema planiranja resursa preduzeća moraju biti u mogućnosti da odgovore na promene i zahteve iz okruženja u realnom vremenu kako bi se odgovorilo na tražnju, definisali uslovi prodaje i kako bi klijenti/potrošači bili na vreme cenovno informisani. 
Kako bi se olakšao protok informacija i njihovo deljenje među organizacijama sistem planiranja resursa preduzeća stvara kolaborativnu atmosferu između članova lanca snabdevanja što dovodi do uvećanja vrednosti duž čitavog lanca. Integracija sistema planiranja resursa preduzeća i elektronskog poslovanja donosi nove izazove u lancu snabdevanja i nov način dodatnog stvaranja vrednosti. Glavni izazov u svemu ovome jeste formiranje okvira koji će obezbediti svim učesnicima lanca snabdevanja dovoljno profitabilan opstanak u takvoj poslovnoj sredini. Koristeći novoformirani okvir za integraciju svih članova lanca snabdevanja kompanije mogu efikasno poslovati u smislu potpunog ispunjenja zahteva svojih klijenata/potrošača i zaokružiti proces difuzije proizvoda odnosno usluge kroz lanac snabdevanja, na način koji ne dovodi do zastoja. Ova integracija je prema nekim istraživanjima i dalje nepouzdana, ne zbog toga što je suviše komplikovana za samo sprovođenje, već zbog toga što ljudski faktor utiče na to da uvek dolazi do sistemskih grešaka koji destabilizuju čitav sistem lanca snabdevanja i poslovanje njegovih partnera.

Bazirano prema rezultatima Delfi metode, mnoge studije su pokazale da se prethodno pomenuti rizik od neadekvatno izvršenog protoka proizvoda odnosno usluge duž lanca snabdevanja može otkloniti sistemom planiranja resursa preduzeća. Ključni nedostaci u primeni sistema planiranja resursa preduzeća, koji bi pomogao u izgradnji efikasnog lanca snabdevanja i integraciji njegovih učesnika, jesu pre svega nedostatak svesti u organizaciji o značaju ovog sistema a samim tim i nedovoljne funkcionalnosti i fleksibilnosti. Ovo se dešava iz prostog razloga što mnoge organizacije nisu u stanju što zbog resursa, što zbog menadžerskog skepticizma, da promene svoju organizacionu infrastrukturu, koja bi se prilagodila i adaptirala sistemu planiranja resursa preduzeća.

Kao što je već gore napomenuto pojava greške u implementaciji sistema planiranja resursa preduzeća koja se javlja u lancu snabdevanja uslovljena je prevelikim osvrtom na interorganizacione odnose a ne i na sagledavanje međuorganizacionih odnosa. Da bi se uspešno sprovela implementacija sistema planiranja resursa preduzeća ona mora biti propuštena kroz prizmu tri različite ali $u$ isto vreme i povezane perspektive:

- Tehnička

- Relaciona

- Menadžerska.

Sistemi planiranja resursa preduzeća pristupaju podacima i aplikacijama pomoću kojih upravljaju integracijom partnera $u$ lancu snabdevanja uz pomoć svoje baze koja je centralizovana ili može biti decentralizovana u zavisnosti od protoka informacija koji najviše odgovara postojećoj strukturi lanca. Kako bi se sve to sagledalo neophodno je stvoriti ambijentalni okvir za usvajanje sistema planiranja resursa preduzeća koji se sastoji od:

- Kompatibilnost sistema planiranja resursa preduzeća i lanca snabdevanja

- Tehnička podrška

- Jedinstvo operacija

- Jedinstvena strategija

- Jedinstvena politika

- Zakonodavni okvir.

Ovaj ambijentalni okvir predstavlja pogodnu bazu za dalje unapređenje integracije poslovnih procesa svih partnera u lancu snabdevanja što se ostvaruje sledećim aktivnostima:

- Koordinacija poslovanja svih učesnika lanca snabdevanja

- Fleksibilnost u protoku informacija i proizvoda odnosno usluga

- Smanjivanje dispariteta u pogledu stručne osposobljenosti za obavljanje određenih zadataka kod partnera u lancu

- Interaktivno upravljanje svim transakcijama u cilju povećanja dinamike i brzine odgovora na tržišne promene.

\section{ZAKLJUČAK}

Današnje organizacije suočavaju se sa naglim i dinamičnim promenama tržišta kao i specifičnim zahtevima potrošača sa elementima personalizacije. Kako bi se tome prilagodile $i$ podigle svoj stepen prilagodljivosti na neki viši nivo neophodno je da se uključe u sistem elektronskog poslovanja kome podršku pruža sistem planiranja resursa preduzeća. Ovakvi pritisci iz spoljnog poslovnog okruženja doslovno 
teraju organizacije da pronalaze nove, inovativnije pristupe koji će im omogućiti efikasan odgovor na sve izazove.

ERP sistem je taj koji pruža organizacijama sigurnosti u elektronskoj trgovini i izazovima koji proizilaze iz elektronskog poslovanja. Ovo podrazumeva i aktivno praćenje novih tehnologija poslovanja na Interneta koje doprinose profitabilnijem poslovanju a povezane su sa ERPom i elektronskim lancem snabdevanja. $\mathrm{Na}$ ovaj način se i sagledava evolutivni aspekt veze između ERP-a i elektronskog poslovanja koji koriste različite ali međusobno komplementarne i dopunjive tehnologije za svoje delovanje. ERP sistem doprinosi rentabilnijem poslovanju i upotrebom sistema sa kojima je usko povezan ako od kojih se izdvajaju kao što je navedeno sistem za upravljanje podacima, sistem za upravljanje transportom, transakcijama kao i sistem za upravljanje odnosima sa potrošačima. Svi ovi sistemi pružaju zajedno kvalitetniji prenos informacija ali veću sposobnost za deljenje informacija i donošenje odluka koje izražavaju punu poslovnu inteligenciju jedne organizacije. $\mathrm{Na}$ ovaj način se stvara posebna integracioni, višedimenzionalni portal za razmenu informaciju između organizacije i njenih stejkholdera.

Najnovije tendencije u ovoj oblasti odnose se na korišćenje "cloud" platforme kao alata za kolaborativnu manipulaciju podacima unutar elektronskog lanca snabdevanja koja donosi virtuelnu i u realnom vremenu komunikaciju između partnera u lancu. Servisi bazirani na računarstvu u oblaku služe kao podrška odlučivanju i takođe razvijaju poslovnu inteligenciju. Menadžeri organizacije bi svakako trebali da razmotre upotrebu ovog alata i izdvoje dovoljno resursa za virtuelno poslovanje u cilju redukcije troškova i smanjenja pojave grešaka u kanalu lanca.

\section{CITIRANI RADOVI}

Akkermans, H., Bogerd, A., Yucesan, P., \& van Wassenhove, P. E. (2003) The impact of ERP on supply chain management: Exploratory findings from a European Delphi study. European Journal of Operational Research, 146, str. 284-301.

Bendoly, E., \& Kaefer, F. (2004). Business technology complementarities: impacts of the presence and strategic timing of ERP on B2B e commerce technology efficiencies. Omega, 32(5), str. 395405.

Damanpour, F. (2001). E-businesse e-commerce evolution: Perspective and strategy. Managerial Finance, 27(7), str. 16-34.

Farzin, S., \& Nezhad, H. T. (2010). E-Procurement, the golden key to optimizing the supply chains system. World Academy of Science, Engineering and Technology, 66, str. 518-524.

Gartner. (2016, Mar 03). Explore Trending Topics. Retrieved from Gartner group: http://www.gartner.com/technology/home.jsp

Mabert, V.A., Soni A., \& Venkataramanan, M.A. (2003) "Enterprise Resource Planning: Managing The Implementation Process", European Journal of Operational Research 146, str. 302-314.

Oracle. (2016, Mar 01). Oracle E-business Suite. Retrieved from Oracle: http://www.oracle.com/us/products/applications/ebusiness/overview/index.html

Oracle. (2016, Mar 01). Oracle ERP software review. Retrieved from ERP Wisdom: http://www.erpwisdom.com/oracle-erp-review.htm

Oracle. (2016, Mar 01). PeopleSoft. Retrieved from Oracle: http://www.oracle.com/us/products/applications/peoplesoft-enterprise/overview/index.html

Oracle. (2016, Mar 01). Siebel CRM Technology. Retrieved from Oracle: http://www.oracle.com/us/products/applications/siebel/crm-technology/overview/index.html

Scavo, F. (2006, Sep 25). Sun's massive ERP consolidation effort. Retrieved from http://fscavo.blogspot.rs/2006/09/suns-massive-erp-consolidation-effort.html 
Srinivasan, M. \& Dey, A. (2014) Linking ERP and e- business to a Framework of an Integrated e- Supply Chain, Handbook of Strategic e- Business Management, Springer Berlin Heidelberg, Chapter III str. 281-305.

Datum prve prijave: $\quad 30.03 .2016$.

Datum prijema korigovanog članka: $\quad 31.05 .2016$.

Datum prihvatanja članka: 23.06.2016.

Kako citirati ovaj rad? / How to cite this article?

Style - APA Sixth Edition:

Rađenović, Ž. (2016, July 15). ERP sistemi kao podrška elektronskom poslovanju organizacija: Evaluacija mogućih alternativa. (Z. Čekerevac, Ed.) FBIM Transactions, 4(2), 135-145. doi:10.12709/fbim.04.04.02.14

Style - Chicago Sixteenth Edition:

Rađenović, Žarko. 2016. "ERP sistemi kao podrška elektronskom poslovanju organizacija: Evaluacija mogućih alternativa." Edited by Zoran Čekerevac. FBIM Transactions (MESTE) 4 (2): 135-145. doi:10.12709/fbim.04.04.02.14.

Style - GOST Name Sort:

Rađenović Žarko ERP sistemi kao podrška elektronskom poslovanju organizacija: Evaluacija mogućih alternativa [Journal] // FBIM Transactions / ed. Čekerevac Zoran. - Belgrade : MESTE, July 15, 2016. 2 : Vol. 4. - pp. 135-145.

\section{Style - Harvard Anglia:}

Rađenović, Ž., 2016. ERP sistemi kao podrška elektronskom poslovanju organizacija: Evaluacija mogućih alternativa. FBIM Transactions, 15 July, 4(2), pp. 135-145.

Style - ISO 690 Numerical Reference:

ERP sistemi kao podrška elektronskom poslovanju organizacija: Evaluacija mogućih alternativa. Rađenović, Žarko. [ed.] Zoran Čekerevac. 2, Belgrade : MESTE, July 15, 2016, FBIM Transactions, Vol. 4, pp. 135-145. 